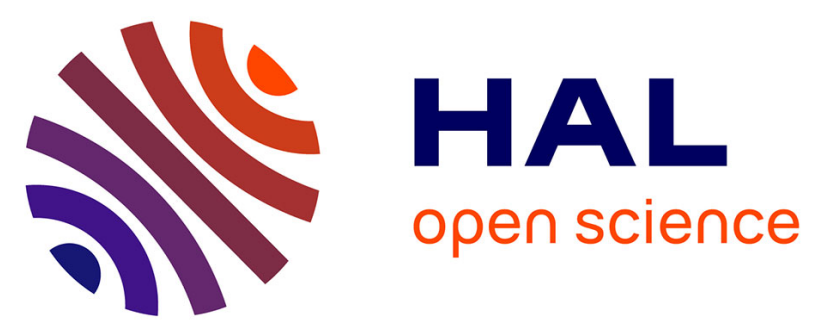

\title{
Early Cretaceous subsidence of the Naturaliste Plateau defined by a new record of volcaniclastic-rich sequence at IODP Site U1513
}

\author{
Eun-Young Lee, Erik Wolfgring, Maria Luisa G. Tejada, Dennis L. Harry, \\ Carmine C. Wainman, Seung Soo Chun, Bernhard Schnetger, Hans-Jürgen \\ Brumsack, Alessandro Maritati, Mathieu Martínez, et al.
}

\section{To cite this version:}

Eun-Young Lee, Erik Wolfgring, Maria Luisa G. Tejada, Dennis L. Harry, Carmine C. Wainman, et al.. Early Cretaceous subsidence of the Naturaliste Plateau defined by a new record of volcaniclastic-rich sequence at IODP Site U1513. Gondwana Research, 2020, 82, pp.1-11. 10.1016/j.gr.2019.12.007 . insu-02448075

\section{HAL Id: insu-02448075 \\ https://hal-insu.archives-ouvertes.fr/insu-02448075}

Submitted on 22 Jan 2020

HAL is a multi-disciplinary open access archive for the deposit and dissemination of scientific research documents, whether they are published or not. The documents may come from teaching and research institutions in France or abroad, or from public or private research centers.
L'archive ouverte pluridisciplinaire HAL, est destinée au dépôt et à la diffusion de documents scientifiques de niveau recherche, publiés ou non, émanant des établissements d'enseignement et de recherche français ou étrangers, des laboratoires publics ou privés. 


\section{Journal Pre-proof}

Early Cretaceous subsidence of the Naturaliste Plateau defined by a new record of volcaniclastic-rich sequence at IODP Site U1513

Eun Young Lee, Erik Wolfgring, Maria Luisa G. Tejada, Dennis L. Harry, Carmine C. Wainman, Seung Soo Chun, Bernhard Schnetger, Hans-Jürgen Brumsack, Alessandro Maritati, Mathieu Martinez, Carl Richter, Yong-Xiang Li, Laurent Riquier, Kenneth G. MacLeod, Thomas R. Waller, Irina Borissova, Maria Rose

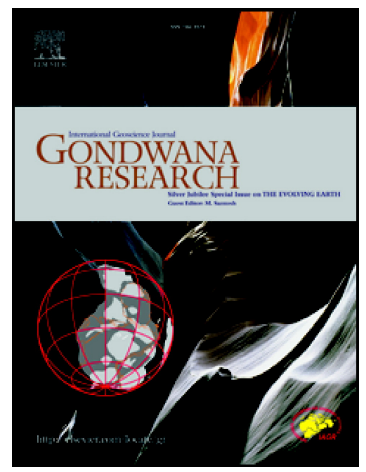
Petrizzo, Brian T. Huber, Yongmi Kim, IODP Expedition 369 Science Party

PII: S1342-937X(20)30027-7

DOI: $\quad$ https://doi.org/10.1016/j.gr.2019.12.007

Reference:

GR 2276

To appear in:

Gondwana Research

Received date: $\quad 29$ July 2019

Revised date: $\quad 10$ December 2019

Accepted date: $\quad 15$ December 2019

Please cite this article as: E.Y. Lee, E. Wolfgring, M.L.G. Tejada, et al., Early Cretaceous subsidence of the Naturaliste Plateau defined by a new record of volcaniclastic-rich sequence at IODP Site U1513, Gondwana Research(2020), https://doi.org/10.1016/ j.gr.2019.12.007

This is a PDF file of an article that has undergone enhancements after acceptance, such as the addition of a cover page and metadata, and formatting for readability, but it is not yet the definitive version of record. This version will undergo additional copyediting, typesetting and review before it is published in its final form, but we are providing this version to give early visibility of the article. Please note that, during the production process, errors may be discovered which could affect the content, and all legal disclaimers that apply to the journal pertain. 
(C) 2020 Published by Elsevier. 
[GR Letter]

\section{Early Cretaceous subsidence of the Naturaliste Plateau defined by a new record of volcaniclastic-rich sequence at IODP Site U1513}

Eun Young Lee ${ }^{\mathrm{a} *}$, Erik Wolfgring ${ }^{\mathrm{b}}$, Maria Luisa G. Tejada ${ }^{\mathrm{c}}$, Dennis L. Harry ${ }^{\mathrm{d}}$, Carmine C. Wainman ${ }^{\mathrm{e}}$, Seung Soo Chun ${ }^{\mathrm{a}}$, Bernhard Schnetger ${ }^{\mathrm{f}}$, Hans-Jürgen Brumsack ${ }^{\mathrm{f}}$, Alessandro Maritati $^{\mathrm{g}}$, Mathieu Martinez ${ }^{\mathrm{h}}$, Carl Richter ${ }^{\mathrm{i}}$, Yong-Xiang Li ${ }^{\mathrm{j}}$, Laurent Riquier ${ }^{\mathrm{k}}$, Kenneth G. MacLeod $^{1}$, Thomas R. Waller ${ }^{\mathrm{m}}$, Irina Borissova ${ }^{\mathrm{n}}$, Maria Rose Petrizzo $^{\mathrm{o}}$, Brian T. Huber ${ }^{\mathrm{m}}$, Yongmi Kim ${ }^{\mathrm{p}}$, IODP Expedition 369 Science Party $^{\mathrm{q}}$

${ }^{a}$ Faculty of Earth Systems and Environmental Sciences, Chonnam National University, Gwangju 61186, Republic of Korea

${ }^{b}$ Department of Geodynamics and Sedimentology, University of Vienna, Vienna 1090, Austria

${ }^{c}$ Institute for Marine Geodynamics (IMG), Japan Agency for Marine-Earth Science and Technology, Kanagawa 237-0061, Japan

${ }^{d}$ Department of Geosciences, Colorado State University, Fort Collins, CO 80523, USA

${ }^{e}$ Australian School of Petroleum, University of Adelaide, Adelaide, SA 5005, Australia

${ }^{f}$ Institut für Chemie und Biologie des Meeres (ICBM), Carl von Ossietzky Universität Oldenburg, Oldenburg 26111, Germany

${ }^{g}$ Institute for Marine and Antarctic Studies (IMAS), University of Tasmania, TAS 7004, Australia

${ }^{h}$ Géosciences Rennes, University of Rennes, CNRS, Rennes 35042, France 
${ }^{i}$ School of Geosciences, University of Louisiana at Lafayette, Lafayette, LA 70504, USA

${ }^{j}$ School of Earth Sciences and Engineering, Nanjing University, Nanjing 210046, China

${ }^{k}$ Institut des Sciences de la Terre de Paris (ISTeP), Sorbonne University, Paris 75005,

France

${ }^{l}$ Department of Geological Sciences, University of Missouri, Columbia, MO 65211, USA

${ }^{m}$ National Museum of Natural History, Smithsonian Institution, Washington DC 20560, USA

${ }^{n}$ Geoscience Australia, Canberra, ACT 2601, Australia

${ }^{o}$ Department of Earth Sciences, Università degli Studi di Milano, Milano 20133, Italy

${ }^{p}$ Petroleum Resources Technology, Korea University of Science and Technology, Daejeon

34113, Republic of Korea

${ }^{q}$ http://iodp.tamu.edu/scienceops/precruise/swaustralia/participants.html

Corresponding authors: Eun Young Lee (eun.y.lee@chonnam.ac.kr)

\section{Keywords}

Naturaliste Plateau; volcaniclastic-rich sequence; subsidence; East Gondwana breakup; IODP Site U1513

\section{Graphical abstract}

\section{Abstract}

The Naturaliste Plateau is a submarine continental ribbon rifted from the southwest Australian margin during the Early Cretaceous breakup of East Gondwana. It occupied a key 
position near the juncture of Greater India and the boundary between Australia and Antarctica. However, details of the Early Cretaceous evolution of the plateau are not well known because of limited data. Drilling at Site U1513 during IODP Expedition 369 recovered the first complete Lower Cretaceous succession on the eastern Naturaliste Plateau. The succession includes syn-rift volcanic rocks, Hauterivian to early Aptian volcaniclasticrich sedimentary rocks, and Albian claystone strata. The 235-m thick volcaniclastic-rich sequence represents the missing post-breakup record in the southwest Australian rifted margin. It spans the transition from syn- to post-rift phase during the final stages of breakup between Greater India and Australia-Antarctica. We report the lithological, petrophysical, geochemical, paleontological, and paleomagnetic characteristics of the sequence, and then synthesize the results to define the Early Cretaceous depositional environment and subsidence history of the Naturaliste Plateau. From the early Hauterivian, weathered volcanic products were eroded and re-deposited locally as a volcaniclastic-rich sequence, with a major contribution from the southern Naturaliste Plateau. The depositional environment evolved from a shelf to upper bathyal condition during the Hauterivian through early Barremian with a decreasing sedimentation rate. This period is defined as a late syn-rift subsidence phase by NW-SE trending extension. After the final breakup with Greater India, the plateau remained at upper bathyal depths with little deposition until the early Aptian. Mid-lower bathyal depths inferred from the Albian claystone strata suggest that the post-rift thermal subsidence commenced during the late Aptian. This two-phase post-rift subsidence reflects the proximity or high temperature of mantle plume, possibly the Kerguelen plume, and its westward migration relative to the southwest Australian rifted margin. 


\section{Introduction}

The Naturaliste Plateau is a large submarine continental block located $260 \mathrm{~km}$ west of the Australian continent (Fig. 1A; Borrisova, 2002; Halpin et al., 2008). It is underlain by thinned continental curst (20-25 km; Olierook et al., 2016) displaced from the southwestern Australian rifted margin, which is defined as a continental ribbon (Peron-Pinvidic and Manatschal, 2010). The Naturaliste Plateau is separated from the Australian continent by the Naturaliste Trough to the east, which is a bathymetric feature overlying the deep-water Mentelle Basin, and by the Perth Basin, which is a rift basin located beneath the continental shelf (Fig. 1). During the Early Cretaceous breakup of East Gondwana, the Naturaliste Plateau occupied a key position near the juncture of what would become the Greater Indian, Australian and Antarctic plates (Fig. 2A), and was also near the projected position of the Kerguelen plume (Gaina et al., 2007; Gibbons et al., 2012, 2013; Veevers et al., 1991; Whittaker et al., 2013; Williams et al., 2011). Its tectonic history thus is central to understanding the breakup of East Gondwana and the role of the Kerguelen plume on continental rifting. However, the Early Cretaceous evolution of the Naturaliste Plateau during and after the breakup has not been well established due to limited drilling and sparseness of geophysical data (Borissova, 2002; Borissova et al., 2010).

During International Ocean Discovery Program (IODP) Expedition 369, five boreholes were drilled at Site U1513 on the eastern flank of the Naturaliste Plateau (Fig. 1; Huber et al., 2019). A primary goal of the expedition was to recover the Cretaceous sedimentary succession and the first in-situ samples of underlaying volcanic rocks, which provide stratigraphic control on the age and nature of the post-breakup succession in the southwest Australian rifted margin. In composite, drilling at Site U1513 recovered a succession of Cretaceous strata from the late Valanginian to the Campanian (Huber et al., 2019). The Early 
Cretaceous succession at Site U1513 includes the syn-rift volcanic rocks overlying the breakup unconformity, Hauterivian to early Aptian sedimentary rocks containing abundant volcanic clasts, and Albian claystone strata (Fig. 1B). In particular, the $235 \mathrm{~m}$-thick volcaniclastic-rich sequence at Site U1513 provides the first complete record that spans the transition from syn- to post-rift phase during the final stages of breakup between Greater India and Australia-Antarctica. It represents the missing stratigraphic record of post-breakup events in the onshore southwest Australian rifted margin (Norvick, 2004; Olierook et al., 2015c). Using a combination of shipboard and post-expedition data, we describe and interpret the lithological, petrophysical, geochemical, paleontological, and paleomagnetic characteristics of the sequence, and then assess the depositional environment. Based on these results and inferences, we discuss the Early Cretaceous subsidence history of the Naturaliste Plateau and its implications for the post-breakup evolution of the southwest Australian rifted margin.

\section{Geologic setting}

The Naturaliste Plateau covers $90,000 \mathrm{~km}^{2}$ in water depths of 2,000-5,000 m that are elevated up to 2,500 $\mathrm{m}$ above the surrounding seafloor (Fig. 1A; Borissova, 2002). It is bounded by transform margins to the north adjacent to the Perth Abyssal Plain and to the southwest along the Naturaliste Fracture Zone, and by a rifted margin on the west that formed during the final stages of separation between Greater India and Australia. Its eastern flank is covered by the western Mentelle Basin (water depths of 2,000-4,000 m; Fig. 1B). The southern edge of the plateau is a steep faulted margin that formed during Late Cretaceous rifting between Australia and Antarctica (Borissova, 2002; Borissova et al., 2010).

Seafloor spreading began on the Cuvier and Perth Abyssal Plains and western Australian margins to the north of the Naturaliste Plateau during the late Valanginian, and propagated 
westwards through the Hauterivian (Fig. 2A). The spreading ridge in the Perth Abyssal Plain established the western edge of the plateau during the early Barremian, which marked the final separation between Greater India and Australia-Antarctica (Colwell et al., 1994; Direen et al., 2008; Gaina et al., 2007; Gibbons et al., 2012, 2013; Markl, 1978; Olierook et al., 2015a; Veevers and Li, 1991; Williams et al., 2013). The late rifting stage was accompanied by volcanic eruptions on sections of the conjugate continental margins around the periphery of the eastern Indian Ocean, as well as on continental blocks and oceanic plateaus (Fig. 2; Colwell et al., 1994; Direen et al., 2008; Olierook et al., 2015a, 2017; Symonds et al., 1998; Whittaker et al., 2016; Zhu et al., 2009). On the southwest Australian rifted margin, basaltic rocks are exposed onshore as the Bunbury Basalt (Frey et al., 1996; Olierook et al., 2015b, 2016), and were dredged from the Naturaliste Plateau (Coleman et al., 1982; Direen et al., 2017; Mahoney et al., 1995). This volcanic activity was followed by deposition of volcanicrich clastic sediments around the newly formed Indian Ocean (Sykes and Kidd, 1994; Vallier and Kidd, 1977) and along the Tethyan-Himalaya (Ghose et al., 2017; Hu et al., 2010), which during the Early Cretaceous was adjacent to the western margin of Australia (Fig. 2). The presence of a volcaniclastic-rich sequence on the Naturaliste Plateau was previously inferred from seismic reflection data (Borissova, 2002) and its topmost section cored at Deep Sea Drilling Project (DSDP) Site 258 (Davies et al., 1974), which is located $1.1 \mathrm{~km}$ westsouthwest of Site U1513 (Fig. 1A).

\section{Materials and methods}

IODP Expedition 369 drilled five holes at Site U1513 (Latitude $33^{\circ} 47.62^{\prime}$ S, Longitude $112^{\circ} 29.13^{\prime} \mathrm{E}$ at Hole U1513D) (Huber et al., 2019). Core recovery was $80.5 \%$ and reached a total depth of 774.0 meters below seafloor (mbsf) at Hole U1513E. The core-sections were systematically described aboard the ship at the macroscopic scale, and smear slides and thin- 
sections were described at the microscopic scale. After the expedition, the core-sections of the volcanic and volcaniclastic-rich sequences were re-examined at the Kochi Core Center (KCC), Japan, and additional thin-sections were described. Lithology, mineralogical composition, grain size, sedimentary structures, bed thickness, and paleontological observations from shipboard data were augmented and revised by post-expedition analyses.

Bulk rock X-ray fluorescence (WD-XRF) composition analysis of 129 samples from Site U1513 was conducted using AXIOS Plus (Panalytical) at Institute for Chemistry and Biology of the Marine Environment (ICBM) of the Carl von Ossietzky University after the expedition. Borate glass beads were prepared from the sample powder using di-lithium tetraborate as a flux (700 mg sample, $4.2 \mathrm{~g}$ flux). Six additional samples of the volcaniclastic-rich sequence were analyzed using AXIOS (Panalytical) at Chonnam National University. Pellets were prepared from the sample powder mixed with wax binder ( $3 \mathrm{~g}$ sample, $0.3 \mathrm{~g}$ wax $\mathrm{C}_{18} \mathrm{H}_{36} \mathrm{O}_{2} \mathrm{~N}_{2}$ ). Whole-rock X-ray diffraction (XRD) measurement and mineral identification were conducted during the expedition (Huber et al., 2019). After the expedition, whole-rock XRD was measured and identified for nine additional samples of the volcaniclastic-rich sequence at Korea Basic Science Institute (KBSI) using a D8 Advance diffractometer with a $\mathrm{Cu}$ source, voltage of $40 \mathrm{kV}$, current of $40 \mathrm{~mA}$ and measurement range of $8^{\circ}-80^{\circ} 2 \theta$.

Selected samples were analyzed for calcareous nannofossils and planktonic and benthic foraminifera during the expedition (Huber et al., 2019). Only benthic foraminiferal specimens were recovered from the volcaniclastic-rich sequence. After the expedition, eight samples were analyzed for palynomorphs at Korea Institute of Geoscience and Mineral Resources (KIGAM), using a standard palynological pretreatment method. The palynomorphs were identified based on illustrations and associated with texonomic descriptions from the Perth 
Basin (Backhouse, 1988) by MGPalaeo. Shell fragments in the volcaniclastic-rich sequence were identified from shipboard photographs at the Smithsonian Institution.

Porosity values measured during the expedition (Huber et al., 2019) were used to estimate the compaction trend for the Cretaceous succession at Site U1513. The trend was used to reconstruct the sedimentation rate and subsidence curve with the BasinVis 2.0 program (Lee et al., 2019, in press). Magnetic susceptibility was measured on the split-core surface $(2.5 \mathrm{~cm}$ interval measurement) during the expedition (Huber et al., 2019). Natural remanent magnetization (NRM) was measured and stepwise demagnetized on all core-sections and selected discrete samples during the expedition (Huber et al., 2019). Geomagnetic polarity reversal sequences were identified from the magnetic inclinations at $20 \mathrm{mT}$ alternating field and were correlated to the Geomagnetic Polarity Time Scale (Ogg et al., 2012, 2016).

\section{Results and interpretation}

\subsection{Lithostratigraphy of Site U1513 and geochemical discrimination}

The cored section from Site U1513 is divided into six Lithostratigraphic Units, I to VI (Fig. 3A; Huber et al., 2019). The lowermost Unit VI consists of alternating altered basaltic flows and volcaniclastic rocks, cut by multiple dolerite dikes. Vesicular texture with brown to red colored oxidation is dominant in the basalt flows, which indicate volcanic eruption and emplacement in subaerial to shallow water setting (Huber et al., 2019; Tejada et al., in press). Strong seismic reflectors from the volcanic sequence (Fig. 1B) are manifest throughout the Naturaliste Plateau and the western Mentelle Basin (Borissova, 2002; Borissova et al., 2010). The volcaniclastic-rich sedimentary sequence is Unit V at Site U1513, which we correlated to Unit V of DSDP Site 258 (an 11 m thick glauconitic sandstone with lithic fragments and detrital claystone; Davies et al., 1974) (Fig. 3A). The boundary between Units VI and V, 
cored in Hole U1513E (interval 2R-4, 0-3 cm), is defined by an irregular contact with an altered basalt flow (Tejada et al., in press). Seismic reflection data show that Unit V is present only to the Naturaliste Plateau (Fig. 1B). Units IV to III consist of Albian to Cenomanian claystone strata, and Units II to I comprise Upper Cretaceous to Neogene chalk and ooze. The boundary between Units V and IV occurs at a transition from sandstone to claystone and coincides with a decrease in magnetic susceptibility (Fig. 3A). Unit IV to Unit I thicken eastward from the flank of the Naturaliste Plateau into the western Mentelle Basin, and from there thin further eastward over the eastern Mentelle Basin and Yallingup Shelf (Fig. 1B).

Previous studies (e.g., Coleman et al., 1982) have correlated Unit V at Site 258 laterally with Unit IV at DSDP Site 264 (altered volcaniclastic conglomerates; Hayes et al., 1975), which is located near the southern edge of the Naturaliste Plateau (Fig. 1A). However, the lithological characteristics of Unit IV at Site 264 (volcanic pebbles and granules embedded in highly altered clayey to sandy or tuffaceous matrix; Ford, 1975) are inconsistent with Unit V of Sites U1513 and 258. The volcaniclastic conglomerate section at Site 264 is more similar to altered volcaniclastic flows intercalated with basalt flows of Unit VI at Site U1513 (Tejada et al., in press).

The Al-Zr-Ti ternary plot (Fig. 3B) discriminates the volcaniclastic-rich sedimentary rocks (Unit V) from sediments and sedimentary rocks of Units I to IV and from the basalt flows and volcaniclastic beds of Unit VI. Relatively high Ti contents of Units V and VI are attributed to the presence of volcanic clasts and minerals such as pyroxene. However, the Al$\mathrm{Zr}$-Ti composition of Unit $\mathrm{V}$ cannot be explained by a simple mixture of weathered volcanic materials derived from the underlying volcanic rocks (Unit VI) with clay minerals (represented by Al), because of their relatively high $\mathrm{Zr}$ contents. The composition of Unit $\mathrm{V}$ 
may be attributed to volcanic material sources with relatively high $\mathrm{Zr}$ content, similar to the basalt fragments dredged from the southern Naturaliste Plateau (Fig. 3B). Alternatively, a winnowing effect induced by bottom currents may lead to heavy mineral enrichments (e.g., zircon) compared to clay minerals (e.g., Atar et al., 2019; Schnetger et al., 2000).

\subsection{Lithostratigraphic subunits of Unit $\mathrm{V}$}

The 235.33 m-thick volcaniclastic-rich sequence (Unit V) at Site U1513 was recovered between 454.92 to 690.25 mbsf (interval U1513D-41R-4, $90 \mathrm{~cm}$, through 66R-1, $8 \mathrm{~cm}$ ) in Hole U1513D and from 685.2 to 688.07 mbsf (interval U1513E-2R-1, 0 cm, through 2R-3, $100 \mathrm{~cm}$ ) in Hole U1513E. We subdivide the volcaniclastic-rich sequence into four Subunits 1-4, numbered from the top downward (Fig. 4A). The major lithological characteristics and sedimentary facies of each subunit are as follows (core-section images in Fig. 4B). Subunit 4 (554.77-690.25 mbsf) consists of coarse to fine-grained, angular to sub-rounded greenishblack, gray to dark/reddish/greenish gray sandstones and dark gray clayey sandstones with abundant glauconite. These are interbedded with siltstone, clayey siltstone, silty claystone, and silty sandstone layers. This subunit is generally massive with a few layered intervals containing parallel or cross laminations. There are a few examples of normal or inverse grading, slump facies, ripples, and soft-sediment deformation. Subunit 3 (498.47-554.77 mbsf) is massive and consists of dark gray to greenish-black siltstones and dark gray silty claystone with sub-angular to sub-rounded grains. Within this unit, grain sizes vary from clay to very fine sand. Subunit $2(472.18-498.47 \mathrm{mbsf})$ is a dark reddish-gray silty claystone with sub-angular and sub-rounded grains. This subunit exhibits parallel laminations, and normal grading is evident in interbedded coarse to fine-grained sandstone layers. Subunit 1 (454.92$472.18 \mathrm{mbsf}$ ) is gray to dark greenish-gray, coarse to fine-grained sandstone with angular to 
sub-rounded grains. The sandstone is generally massive with interbeds containing parallel or cross laminations. A few intervals exhibit normal grading.

The volcanic clasts and lithic fragments are abundant throughout Unit $\mathrm{V}$, and are evident macroscopically in the sandstones of subunit 4 (Fig. 4B and C). Ca and Na-rich feldspar (e.g., labradorite), montmorillonite, and chlorite are dominant throughout the sequence, while kaolinite is dominant in the silty claystone of subunit 2 (Supplementary material 1). These minerals are attributed to weathering and erosion of volcanic rocks and materials (e.g., Bain et al., 1980; Hathon and Underwood, 1991; Sykes and Kidd, 1994). Primary ash or pyroclastic layers were not observed in Unit V. It is thus interpreted to consist of epiclastic deposits, which are not deposited by explosive volcanism and its direct effects (e.g., pyroclastic flow) (Manville et al., 2009 and references therein). Hydrothermal alteration is observed throughout Unit V with a few hydrothermal veins. Calcite cementation is present in subunits 1, 3, and 4 filling inclined and irregular shaped veins with minor fault offsets and slickensides. Pyrite nodules are present throughout all four units with carbonate and siderite nodules present only in subunit 3.

\subsection{Paleontological observations}

Bioturbation and organic matter are common in subunits 4 and 3 of Unit V, decreasing upward in the section (Fig. 4C). Subunit 4 shows intense bioturbation and trace fossils (e.g., Macaronichnus, Teichichnus) with burrows, borings and horizontal structures indicative of the Skolithos and Cruziana ichnofacies that are typically present from the low-tide zone to the edge of the continental shelf (Knaust, 2017; Seilacher, 1967). A few trace fossils and bioturbated lamination contacts are observed in subunits 2 and 1. Shell fragments are abundant in subunits 4 and 3 (Fig. 4C). Shell fragments are 2-4 mm thick and up to several centimeters long but are generally too fragmented and/or not exposed well enough on cut or 
broken core surfaces to be confidently identified. Two individuals were identified as Neithea sp. and a third, tentatively, as Cteniopleurium sp. The former is a fairly common Lower Cretaceous genus (Hayami, 1975), whereas the latter was originally described from the Santonian Gingin Chalk of Western Australia (Feldtman, 1951). If the generic identification of the latter is correct, this would be the first occurrence of this taxon from Lower Cretaceous strata. Both are found in inner to middle shelf environments and interior basins. Plant debris is present throughout Unit V and abundant in subunit 4.

Benthic foraminiferal specimens with limited biostratigraphic and paleoenvironmental significance were recovered in subunits 4 and 3 of Unit V. Specimens of Praebulimina sp. and Lenticulinella sp. are identified from Samples U1513D-50R-CC (543.98 mbsf) and U1513D-52R-CC (564.43 mbsf). A specimen of Quinqueloculina? sp. was recovered from Sample U1513D-48R-CC (525.76 mbsf). Benthic foraminifera present belong to the opportunistic, environmentally tolerant benthic taxon Lenticulina spp., the resilient taxon Praebulimina sp., and the miliolid taxon Quinqueloculina? sp. (Holbourn et al., 1999; Reolid and Martínez-Ruiz, 2012). These benthic foraminiferal taxa have extensive depth ranges from inner neritic to lower bathyal, but their highest abundance is found in outer shelf environments (Gräfe and Wendler, 2003; Holbourn and Moullade, 1998; Murray, 1991, 2006). In the overlying Unit IV, agglutinated foraminiferal taxa are dominant with Glomospira spp. and the most abundant taxa, Kalampsis sp. and Nothia sp. Few calcareous benthic foraminiferal markers for deep-sea environments (Gavelinella sp., Cibicidoides spp., Osangularia spp.) are present in some cores. The benthic foraminiferal assemblage in Unit IV indicates middle to lower bathyal depths as well as an open marine depositional environment (Kaminski and Gradstein, 2005; Tjalsma and Lohmann, 1983; van Morkhoven et al., 1986). 
In several samples of Units V and IV, a few dinoflagellate cysts, phytoclasts, spores and pollen were identified (Fig. 4C). Subunit 3 of Unit V includes specimens of Leptodinium/Impagidinium sp. (Sample U1513D-50R-1, 33-35 cm; $536.94 \mathrm{mbsf}$ ), and Apteodinium sp. and Circulodinium hystrix/vannophorum (Sample U1513D-46R-3, 61-63 cm; 501.62 mbsf). In the Perth Basin (Fig. 1A), Apteodinium sp. has an age range from the Hauterivian to the Aptian, although Backhouse (1988) estimates a longer range for this taxon. Circulodinium hystrix/vannophorum has an age range from the Valanginian to the Aptian (Backhouse, 1988) and can be associated with marginal, brackish, coastal, nearshore environments with unstable conditions or high environmental stress (Carvalho et al., 2016). In the lowermost claystone of the overlying Unit IV (Sample U1513D-41R-1, 85-87 cm; 451.06 mbsf), Spiniferites sp., Cribroperidinium edwardsii, and Apteodinium granulatum are present (Fig. 4C). These taxa have age ranges that span the Early Cretaceous in the Perth Basin (Backhouse, 1988; Helby et al., 1987) and may suggest an inner neritic environment (Carvalho et al., 2016), although reworking from a source upslope is possible.

\subsection{Magnetostratigraphy and sedimentation rate of Unit $\mathrm{V}$}

Well-defined magnetic polarity sequences allow us to establish a high resolution magnetostratigraphy and an age-depth model for the volcaniclastic-rich sequence (Fig. 5A;

Supplementary material 2). The uppermost $0.5 \mathrm{~m}$ of the sequence correlates with the beginning of the long Cretaceous Normal Superchron, chron C34n (125.93-83.64 Ma) (Ogg et al., 2012), which extends upward into the lower part of Unit II (Huber et al., 2019). In the remainder of the volcaniclastic-rich sequence, between 690.25 and 455.47 mbsf, eighteen polarity sequences are distinguished, spanning chrons M10Nn.1n to M0r (134.48-125.93 Ma; Ogg et al., 2012). Unit V was thus deposited from the Hauterivian to the early Aptian (Ogg et al., 2016), and more than two thirds of total thickness of this sequence accumulated during 
the Hauterivian (Fig. 5A). The beginning of chron M10Nn.1n (134.48 Ma) is missing at Site U1513. The chron ended at 134.22 Ma, giving a minimum age for the volcanic sequence of Unit VI. The boundary with underlying Unit VI is defined by a polarity reversal, as well as an irregular contact, which suggests a time gap between the volcaniclastic-rich deposition and the topmost basalt flow.

The magnetostratigraphy of Unit V allows a detailed reconstruction of the sedimentation rate. The strata within each geomagnetic polarity epoch were decompacted to determine layer thickness prior to burial using the onsite compaction trend and BasinVis 2.0 program (Supplementary material 2; Lee et al., in press). The decompacted thickness was combined with the duration of each geomagnetic chron to reconstruct the sedimentation rate. The sedimentation rate varies, but shows an overall decrease upward in the section (Fig. 5B). High sedimentation rates are recorded in the early Hauterivian, during chrons M10Nn.1n (<134.48-134.22 Ma; >183 m/myr), M10r (134.22-133.88 Ma; 298 m/myr) and M9r (133.58-133.3 Ma; $136 \mathrm{~m} / \mathrm{myr}$ ). The sedimentation rate for chron M10Nn.1n is a minimum rate, as the bottom (oldest) part of the chron is not recovered in the core. The sedimentation rate is much lower from the late Hauterivian to early Aptian, ranging from 1 to $40 \mathrm{~m} / \mathrm{myr}$.

Recent studies have suggested new ages for the geomagnetic chrons in the Valanginian to Aptian stages, based on numerical U-Pb and Ar-Ar ages intercalibrated with astrochronology (Aguirre-Urreta et al., 2015, 2019; Martinez et al., 2015; Olierook et al., 2019c). With a difference of 3.5 to $5.5 \mathrm{~m} . \mathrm{y}$., these ages are substantially younger than those proposed in the Geologic Time Scale of Ogg et al. $(2012,2016)$, which suggest <130.9-122.3 Ma for chrons M10Nn.1n to M0r of Unit V (Supplementary material 3). It suggests $\sim 130.5 \mathrm{Ma}$ as a minimum age of the underlaying volcanic sequence. The relatively consistent shift of ages maintains the major trends in the age-depth model and sedimentation rate of Unit V. 


\section{Discussion}

\subsection{Early Cretaceous depositional environment}

The age of the volcaniclastic-rich sequence at Site U1513 (134-126 Ma) overlaps with the ages of volcanic rocks dredged from the Naturaliste Plateau (132-128 Ma; Direen et al., 2017), indicating that the deposition of Unit $\mathrm{V}$ was coincided with volcanism on the plateau. However, no direct evidence of explosive volcanic eruption (e.g., ash, pyroclastic flows) was observed in Unit V, and the volcanic clasts and lithic fragments are relatively fine-grained and round-shaped (Fig. 4C). The volcanic component is therefore interpreted to indicate transport from distant volcanic terrains. Based on volcanic edifices imaged on seismic reflection profiles (Borissova, 2002), candidate sources of the volcanic materials in Unit V are the exposed equivalents of the underlying volcanic sequence (Unit VI) and the volcanic terrains of the southern and northern Naturaliste Plateau. We argue that the southern Naturaliste Plateau is a major source of the volcanic materials for the following reasons. Firstly, relatively fine and sub-rounded volcanic grains throughout Unit V (Fig. 4C) indicate a distant source (>125 km to the southern margin from Site U1513). Secondly, the high Zr content in Unit V suggests derivation from volcanic rocks with higher $\mathrm{Zr}$ content than Site U1513 basalts (Fig. 3B). Thirdly, sediment provenances and distribution paths trending parallel to the rift axis are observed in rift basins (e.g., Perth Basin; Olierook et al., 2019a). In the case of the Naturaliste Plateau, the trend points to the southern volcanic terrain as the provenance source.

Montmorillonite, found throughout Unit V, is interpreted to be the result of subaerial weathering and erosion of volcanic rocks. This is consistent with the environmental setting interpreted from the volcaniclastic conglomerate sequence at Site 264 in the southern Naturaliste Plateau. The poorly sorted volcanic fragments and lack of mixing with non- 
volcanic detritus are indicative of a volcaniclastic flow deposit sourced from nearby volcanic terrain, rather than transported by water (Ford, 1975). The adjacent source terrain is potentially part of the volcanic rocks on the southern Naturaliste Plateau, which is supported by the similar geochemical composition between volcanic cobbles at Site 264 and dredged basaltic samples (Fig. 3B). However, alteration involving seawater interaction described from a few volcanic fragments at Site 264 (Ford, 1975) are indicative of subaqueous setting. We interpret that the volcanic terrains on the southern Naturaliste Plateau were emplaced and weathered in a fluctuating environment between subaerial and shallow-water settings. This environmental setting could contribute to the type of clay mineral alteration, subaerial erosion, and subsequent transport to the site of the volcaniclastic-rich deposition on the eastern Naturaliste Plateau.

Paleontological evidence from benthic foraminifera, bivalves, palynomorphs as well as trace fossils suggests a shelfal to shallow bathyal depositional environment for the early Hauterivian to early Barremian (subunit 4 to 3 of Unit V). Together with the regularly changing sedimentary facies and sedimentation rate, the data from benthic foraminiferal assemblages suggest a restricted and shallow marine environment displaying unsteady conditions for the lower part of Unit V. Alternating environmental characteristics, such as variations in oxygenation, nutrient supply or alkalinity, can induce high environmental stress, which makes a habitat unsuitable for most foraminiferal taxa and might result in the depletion of the benthic foraminiferal assemblage and a reduction to few tolerant taxa, respectively. This analysis corresponds to the paleoenvironmental interpretation from palynomorph specimens. Paleontological evidence from the lower part can therefore be interpreted to indicate a marginal marine environment with variations in the terrigenous input, runoff and chemical composition of coastal waters, and changes in shape and nature of the basin area. 
The interpretation of an unstable depositional environment is furthermore supported by the highly variable $\mathrm{Mg} / \mathrm{Al}$ and $\mathrm{Rb} / \mathrm{Al}$ ratios (Fig. 5C), which can be used to infer changes in environmental conditions (e.g., Atar et al., 2019; Martin-Puertas et al., 2010; Schnetger et al., 2000). $\mathrm{Mg}$ and $\mathrm{Rb}$ enrichments are associated with increases in terrigenous/detrital input, fluvial runoff or precipitation. The highly varying $\mathrm{Mg} / \mathrm{Al}$ and $\mathrm{Rb} / \mathrm{Al}$ ratios of the lower part (particularly subunit 4) correlate with the interval of high sedimentation rate. The correlation strongly suggests considerable input from a land mass.

The upper part of Unit V (subunits 2 and 1) was likely deposited in deeper water depths than the lower part, as indicated from the sparsity of fossils and bioturbation, lower sedimentation rate $(1-23 \mathrm{~m} / \mathrm{myr})$, and lower terrigenous influence inferred from the $\mathrm{Mg} / \mathrm{Al}$ ratio (Fig. 5C). The depth increase could be enhanced by a rise in global sea-level ( $60 \mathrm{~m}$; Fig. 6A) during the Hauterivian, which culminated in a highstand during the Barremian (Haq, 2014). We infer that the upper part was deposited in an upper bathyal environment $(200-600 \mathrm{~m})$, which is deeper than the shallow marine of the lower part, but not as deep as the middle to lower bathyal depths (600-2,000 m) of Unit IV. Together with the changes in the benthic foraminiferal assemblage, a significant increase in water depth between Unit V and Unit IV is suggested by the lithologic transition to marine claystone, the absence of volcanic clasts and lithic fragments, and the abrupt decrease in Ti content and magnetic susceptibility.

\subsection{Subsidence history and implications for the post-breakup evolution of the southwest}

\section{Australian rifted margin}

\subsubsection{Syn-rift subsidence phase}

Previous studies (e.g., Borissova, 2002) have interpreted the Hauterivian to early Barremian sequence of the Naturaliste Plateau as a post-rift thermal subsidence phase. However, we 
attribute the interval to the syn-rift subsidence phase. During the early Hauterivian, the Naturaliste Plateau subsided fast ( $370 \mathrm{~m} / \mathrm{myr})$, but high sedimentation rate kept pace with subsidence and maintained the depositional environment in a shallow marine condition (Fig. 6B). The depth increased to an upper bathyal setting through the early Barremian. This subsidence period corresponds to the NW-SE trending extension during 7-8 m.y., led by seafloor spreading in the Perth Abyssal Plain and its westward propagation along the northern margin of the Naturaliste Plateau (Fig. 2A; Gibbons et al., 2012; Hall et al., 2013; Williams et al., 2013). In seismic profiles (Borissova, 2002; Borissova et al., 2010; Maloney et al., 2011), NE-SW trending faults parallel to the seafloor magnetic anomalies and syn-rift structures (e.g., synsedimentary deformation, fault reactivation) are observed in the HauterivianBarremian strata of the Naturaliste Plateau and the Mentelle Basin. Core-sections of Unit V contain multiple fault offsets in subunits 4 and 3. During this phase, the syn-rift volcanism diminished on the Naturaliste Plateau and the onshore southwest Australian margin (Fig. 6B). Most of the Hauterivian to early Barremian strata at Site U1513 are thus a late syn-rift sequence. This syn-rift phase indicates $\sim 550 \mathrm{~m}$ of basement subsidence in addition to the $\sim 60$ m sea-level rise that occurred during this time (Fig. 6), which we attribute to the crust thinning during the extension.

The deepening trend from the late Valanginian (volcanism near sea-level; Unit VI) through the early Barremian at Site U1513 is similar to that observed in the South Perth Shale in the Vlaming Sub-basin of the southern Perth Basin (Fig. 1A). The South Perth Shale was deposited during a marine transgression and a highstand from the late Valanginian to Barremian (Lech et al., 2016). In the eastern Mentelle Basin, the Late Jurassic syn-rift fluviolacustrine deposits transition upward into marine strata (Lithostratigraphic Units IIb and IIa at 
Site U1515), indicating subsidence and marine transgression from the Valanginian (Wainman et al., in press).

\subsubsection{Two-phase post-rift subsidence process}

Classical rift models predict significant thermal subsidence immediately following continental breakup in response to lithospheric cooling in early post-rift time (McKenzie, 1978). After the final breakup between Greater India and Australia-Antarctica during the early Barremian, however, the Naturaliste Plateau remained at upper bathyal depths with low sedimentation rate through to the early Aptian (Fig. 6B). On the southern Perth Basin, faulting and sedimentation ceased virtually from the Barremian (Norvick, 2004; Olierook et al., 2015c). These observations indicate that the southwest Australian rifted margin did not immediately begin to thermally subside after the final breakup during the late Barremian through the early Aptian (Post-rift phase 1; Fig. 6B). Mid-lower bathyal depths from the Albian at Site U1513 suggest the initiation of post-rift thermal subsidence during the late Aptian (Post-rift phase 2; Fig. 6B).

The lack of substantial post-rift thermal subsidence on the southwest Australian rifted margin could be induced by the effects of mantle plume (e.g., thermal buoyancy, mantle instability, small-scale convection; Boston et al., 2019; Dafoe et al., 2017). During this period, the margin might be located within a large influence radius of a mantle plume $(500-1,000 \mathrm{~km}$; White and McKenzie, 1989). Previous works suggest that contemporaneous volcanism along the rifted margins of Greater India (Comei-Cona) and Australia (Bunbury Basalt), together with that on the Naturaliste Plateau (Fig. 2A) formed the 136-124 Ma Large Igneous Province (Direen et al., 2017; Olierook et al., 2016, 2017, 2019b; Watson et al., 2016; Zhu et al., 2009). The scattered mafic rocks across the margins have been explained by either disconnected limbs of the Kerguelen plume or multiple mantle plumes (Coffin et al., 2002; 
Olierook et al., 2016; Whittaker et al., 2016). The proximity or elevated temperature of the Kerguelen plume and/or other plume(s) could account for the relatively shallow depths of the Naturaliste Plateau during the late Barremian through early Aptian. This may be responsible for the latest volcanism ( 128 Ma; Direen et al., 2017) and hydrothermal alteration age at Site 264 (128-123 Ma; Olierook et al., 2017) on the southern Naturaliste Plateau, and hydrothermal veins in subunit 1 of Unit V at Site U1513. Alternatively, a transient thermal anomaly associated with the slow rifting between the Australian and Antarctic plates (Direen et al., 2007) may have kept the southwest Australian margin elevated during the period. However, it is uncertain if this mechanism can explain the onset of thermal subsidence during the late Aptian, which preceded the plate motion change ( 100 Ma; Whittaker et al., 2013) and seafloor spreading ( 83 Ma; Sayer et al., 2001) between Australia and Antarctica.

The post-rift thermal subsidence began during the late Aptian (>54 m/myr; Fig. 6B). The period corresponds to the onset of extensive magmatic activity associated with the volcanism on the Kerguelen Plateau ( $\geq 119$ Ma; Coffin et al., 2002) and the Gulden Draak Knoll ( 117 Ma; Whittaker et al., 2016). It resulted from the westward migration of the Kerguelen plume relative to the southwest Australian margin and associated relocation of spreading center and ridge jumps during the opening of Indian Ocean (Fig. 2B; Gibbons et al., 2012; 2013; Olierook et al., 2017, 2019b; Watson et al., 2016). The relative westward migration of the Kerguelen plume could have removed the thermal buoyancy support on the rifted margin, which triggered the thermal relaxation of thinned lithosphere and the thermal subsidence. This is marked by the extensive deposition of the Albian claystone in an open marine environment, which blanketed most of the Naturaliste Plateau and the Mentelle Basin (Fig. 1B). In seismic profiles, the strata are mostly unfaulted and thicken into the western Mentelle Basin with pinch-out and onlap on the eastern Naturaliste Plateau and the eastern Mentelle 
Basin through to the Yallingup Shelf (Borissova, 2002; Borissova et al., 2010; Maloney et al., 2011). The thick claystone strata in the western Mentelle Basin are likely derived from high thermal subsidence rates, corresponding to significantly thinned crust $(\sim 13 \mathrm{~km})$ beneath the Naturaliste Trough (Johnston et al., 2010; Olierook et al., 2016).

\section{Conclusions}

A 235 m-thick volcaniclastic-rich sedimentary sequence was recovered at IODP Site U1513 on the eastern flank of the Naturaliste Plateau, rifted from the southwest Australian continental margin. The volcaniclastic-rich sequence provides a new and in-depth record of the Early Cretaceous stratigraphy and changes in the depositional environment immediately after the onset of seafloor spreading in the Perth Abyssal Plain. Magnetostratigraphy indicates the deposition during the Hauterivian through early Aptian, which spans the final stages of breakup between Greater India and Australia-Antarctica. The sequence contains abundant volcanic clasts, lithic fragments and clay minerals derived from subaerial weathering and erosion of volcanic products. The coeval volcanic rocks on the southern Naturaliste Plateau are inferred to be a major source of the volcanic materials. A synthesis of sedimentological and paleontological observations, as well as geochemical data, indicates a transition of a shelf to upper bathyal environment with a decreasing sedimentation rate. Our results highlight the Early Cretaceous subsidence history of the Naturaliste Plateau. We define a syn-rift subsidence interval and the two-phase post-rift subsidence process across the southwest Australian rifted margin. During the Hauterivian through early Barremian, the depositional environment evolved from a shelf to upper bathyal setting with decreasing terrestrial input. This progressive deepening corresponds to the syn-rift subsidence by a NWSE extensional regime, which is associated with the seafloor spreading in the Perth Abyssal Plain and its westward propagation. After the final breakup with Greater India to the west of 
the Naturaliste Plateau, the region remained at upper bathyal depths with low sedimentation rate during the late Barremian through early Aptian. This interpretation suggests that the southwest Australian rifted margin had a lack of substantial post-rift thermal subsidence following the final breakup. This pause in subsidence could be induced by the proximity or high temperature of the Kerguelen plume and/or other mantle plume(s). Mid-lower bathyal depths indicated from the extensive Albian claystone strata suggest that the post-rift thermal subsidence commenced during the late Aptian, which corresponds to a period of westward migration of the Kerguelen plume relative to the southwest Australian rifted margin and associated relocation of spreading center and ridge jumps. 


\section{Acknowledgements}

This research used data and samples provided by the International Ocean Discovery Program (IODP). We thank technical staffs of IODP Expedition 369 and crew members of the JOIDES Resolution for their critical contributions, and Geoscience Australia for providing us with invaluable data. We acknowledge financial support by K-IODP by the Ministry of Oceans and Fisheries and KRF program by the Ministry of Science and ICT through the NRF of Korea (2017H1D3A1A01054745) to E.Y.L., Brian J. O’Neill Memorial Scholarship to E.W., J-DESC to M.L.G.T., U.S. Science Support Program Post-Expedition Research Award (70GG00939) to D.L.H., ANZIC supported by the Australian Government through the ARC LIEF Grant (LE160100067) to C.C.W., A.M. and L.W., and ECORD and IODP-France to L.R. and M.M. Special thanks go to Daniel Mantle and Adam Charles (MGPalaeo) for palynological analysis, to Michael Wagreich, Susanne Gier and the KBSI Gwangju Center for sample analysis, and to Yusuke Kubo, Shigako Nigi and Ryo Yamaoka of the KCC for facilitating our visit and core descriptions (Request No. 071241IODP). We thank C. Lehners and E. Gruendken from the Microbiogeochemistry group at the ICBM for sample preparation and XRF analysis. This manuscript was improved significantly from the thorough reviews of H.K.H. Olierook, two anonymous reviewers and the editorial handling of M. Santosh. 


\section{References}

Aguirre-Urreta, B., Martinez, M., Schmitz, M., Lescano, M., Omarini, J., Tunik, M., Kuhnert, H., Concheyro, A., Rawson, P.F., Ramos, V.A., Reboulet, S., Noclin, N., Frederichs, T., Nickl, A-L., Pälike, H., 2019. Interhemispheric radio-astrochronological calibration of the time scales from the Andean and the Tethyan areas in the Valanginian-Hauterivian (Early Cretaceous). Gondwana Research 70, 104-132.

Aguirre-Urreta, B., Lescano, M., Schmitz, M.D., Tunik, M., Concheyro, A., Rawson, P.F., Ramos, V.A., 2015. Filling the gap: new precise Early Cretaceous radioisotopic ages from the Andes. Geological Magazine 152, 557-564.

Atar, E., März, C., Schnetger, B., Wagner, T., Aplin, A., 2019. Local to global controls on the deposition of organic-rich muds across the Late Jurassic Laurasian Seaway. Journal of the Geological Society 176, 1143-1153.

Backhouse, J., 1988. Late Jurassic and Early Cretaceous palynology of the Perth Basin, Western Australia, Bulletin 135. Geological Survey of Western Australia, Perth.

Bain, D.C., Ritchie, P.F.S., Clark, D.R., Duthie, D.M.L., 1980. Geochemistry and mineralogy of weathered basalt from Morvern, Scotland. Mineralogical Magazine 43, 865-872.

Borissova, I., 2002. Geological framework of the Naturaliste Plateau. Geoscience Australia Record 2002/20, Canberra.

Borissova, I., Bradshaw, B.E., Nicholson, C.J., Struckmeyer, H.I.M., Payne, D.S., 2010. New exploration opportunities on the southwest Australian margin - deep-water frontier Mentelle Basin. The APPEA Journal 50, 47-60. 
Borissova, I., Coffin, M.F., Charvis, P., Operto, S., 2003. Structure and development of a microcontinent: Elan Bank in the southern Indian Ocean. Geochemistry Geophysics Geosystems 4, 1071.

Boston, B., Nakamura, Y., Gallais, F., Hackney, R., Fujie, G., Kodaira, S., Miura, S., Kaiho, Y., Saito, S., Shiraishi, K., Yamada, Y., 2019. Delayed Subsidence After Rifting and a Record of Breakup for Northwestern Zealandia. Journal of Geophysical Research: Solid Earth 124, 3057-3072.

Carvalho, M.A., Bengtson, P., Lana, C.C., 2016. Late Aptian (Cretaceous) paleoceanography of the South Atlantic Ocean inferred from dinocyst communities of the Sergipe Basin, Brazil. Paleoceanography and Paleoclimatology 31, 2-26.

Coffin, M.F., Pringle, M.S., Duncan, R.A., Gladczenko, T.P., Storey, M., Müller, R.D., Gahagan, L.A., 2002. Kerguelen hotspot magma output since 130 Ma. Journal of Petrology 43, 1121-1137.

Coleman, P.J., Michael, P.J., Mutter, J.C., 1982. The origin of the Naturaliste Plateau, SE Indian Ocean: Implications from dredged basalts. Journal of the Geological Society of Australia 29, 457-468.

Colwell, J.B., Symonds, P.A., Crawford, A.J., 1994. The nature of the Wallaby (Cuvier) Plateau and other igneous provinces of the West Australian margin. Journal of Australian Geology and Geophysics 15, 137-156.

Dafoe, L.T., Keen, C.E., Dickie, K., Williams, G.L., 2017. Regional stratigraphy and subsidence of Orphan Basin near the time of breakup and implications for rifting processes. Basic Research 29, 233-254. 
Davies, T.A., Luyendyk, B.P., Rodolfo, K.S., Kempe, D.R.C., McKelvey, B.C., Leidy, R.D. et al., 1974. Site 258. In: Davies, T.A., Luyendyk, B.P. et al. (Eds.), Initial Reports of the Deep Sea Drilling Project, Leg 26. U.S. Government Printing Office, Washington DC, $359-414$.

Direen, N.G., Borissova, I., Stagg, H.M.J., Colwell, J.B., Symonds, P.A., 2007. Nature of the continent-ocean transition zone along the southern Australian continental margin: a comparison of the Naturaliste Plateau, SW Australia, and the central Great Australian Bight sectors. In: Karner, G.D., Manatschal, G., Pinheiro, L.M. (Eds.), Imaging, Mapping and Modelling Continental Lithosphere Extension and Breakup, Vol. 282. Geological Society Special Publications, London, 235-261.

Direen, N.G., Stagg, H.M.J., Symonds, P.A., Colwell, J.B., 2008. Architecture of volcanic rifted margins: new insights from the Exmouth-Gascoyne margin, Western Australia. Australian Journal of Earth Sciences 55, 341-363.

Direen, N.G., Cohen, B.E., Maas, R., Frey, F.A., Whittaker, J.M., Coffin, M.F., Halpin, J.A., Crawford, A.J., 2017. Naturaliste Plateau: constraints on the timing and evolution of the Kerguelen Large Igneous Province and its role in Gondwana breakup. Australian Journal of Earth Sciences 64, 1-19.

Feldtmann, F.R., 1951. Pectens of the Gingin Chalk. Journal of the Royal Society of Western Australia 35, 9-29

Ford, A.B., 1975. Volcanic rocks of Naturaliste Plateau, Eastern Indian Ocean, Site 264, DSDP Leg 28. In: Hayes, D.E., Frakes, L.A. et al. (Eds.), Initial Reports of the Deep Sea Drilling Project, Leg. 28. U.S. Government Printing Office, Washington DC, 821-833. 
Frey, F.A., McNaughton, N.J., Nelson, D.R., deLaeter, J.R., Duncan, R.A., 1996.

Petrogenesis of the Bunbury Basalt, Western Australia: interaction between the Kerguelen plume and Gondwana lithosphere?. Earth and Planetary Science Letters $144,163-183$.

Gaina, C., Müller, R.D., Brown, B., Ishihara, T., Ivanov, S., 2007. Breakup and early seafloor spreading between India and Antarctica. Geophysical Journal International 170, 151-169.

Gibbons, A.D., Barckhausen, U., van den Bogaard, P., Hoernle, K., Werner, R., Whittaker, J.M., Müller, R.D., 2012. Constraining the Jurassic extent of Greater India: tectonic evolution of the West Australian margin. Geochemistry Geophysics Geosystems 13, Q05W13.

Gibbons, A.D., Whittaker, J.M., Muller, R.D., 2013. The breakup of East Gondwana: Assimilating constraints from Cretaceous ocean basins around India into a best-fit tectonic model. Journal of Geophysical Research-Solid Earth 118, 808-822.

Ghose, N.C., Chatterjee, N., Windley, B.F., Subaqueous early eruptive phase of the late Aptian Rajmahal volcanism, India: Evidence from volcaniclastic rocks, bentonite, black shales, and oolite. Geoscience Frontiers 8, 809-822.

Gräfe, K.-U., Wendler , J., 2003. Foraminifers and calcareous dinoflagellate cysts as proxies for deciphering sequence stratigraphy, sea-level change, and paleoceanography of Cenomanian-Turonian hemipelagic sediments in Western Europe. In: Olson, H.C., Leckie, M. (Eds.), Micropaleontologic Proxies for Sea-Level Change and Stratigraphic Discontinuities. SEPM, Special Publication 75, 229-262 
Halpin, J.A., Crawford, A.J., Direen, N.G., Coffin, M.F., Forbes, C.J., Borissova, I., 2008. Naturaliste Plateau, offshore Western Australia: a submarine window into Gondwana assembly and breakup. Geology 36, 807-810.

Haq, B.U., 2014. Cretaceous eustasy revisited. Global and Planetary Change 113, 44-58.

Hathon, E.G., Underwood, M.B., 1991. Clay mineralogy and chemistry as indicators of hemipelagic sediment dispersal south of the Aleutian arc. Marine Geology 97, 145-166.

Hayami, I., 1975. A systematic survey of the Mesozoic Bivalvia from Japan. University of Tokyo Press, Tokyo.

Hayes, D.E., Frakes, L.A., Barrett, P.J., Burns, D.A., Chen, P.-H., Ford, A.B. et al., 1975. Site 264. In: Hayes, D.E., Frakes, L.A. et al. (Eds.), Initial Reports of the Deep Sea Drilling Project, Leg 28. U.S. Government Printing Office, Washington DC, 821-833.

Helby, R., Morgan, R., Partridge, A.D., 1987. A palynological zonation of the Australian Mesozoic. Memoir of the Association of Australasian Palaeontologists 4, 1-94.

Holbourn, A., Kuhnt, W., El Albani, A., Pletsch, T., Luderer, F., Wagner, T., 1999. Upper Cretaceous palaeoenvironmental and benthonic foraminiferal assemblages of potential source rocks from the western African margin, Central Atlantic. In: Cameron, N.R., Bate, R.H., Clure, V.S. (Eds.), The Oil and Gas Habitats of the South Atlantic. Geological Society London, Special Publications 153, 195-222.

Holbourn, A.E.L., Moullade, M., 1998. Lower Cretaceous benthic foraminifer assemblages, equatorial Atlantic: Biostratigraphic, paleoenvironmental, and paleobiogeographic significance. In: Mascle, J., Lohmann, G.P., Moullade, M. (Eds.), Proceedings of the Ocean Drilling Program, Scientific Results, vol. 159. ODP, College Station, TX. 
Hu, X., Jansa, L., Chen, L., Griffin, W.L., O’Reilly, S.Y., Wang, J., 2010. Provenance of Lower Cretaceous Wölong Volcaniclastics in the Tibetan Tethyan Himalaya: Implications for the final breakup of Eastern Gondwana. Sedimentary Geology 223, $193-205$.

Huber, B.T., Hobbs, R.W., Bogus, K.A., Batenburg, S.J., Brumsack, H.-J., do Monte Guerra, R., Edgar, K.M., Edvardsen, T., Harry, D.L., Hasegawa, T., Haynes, S.J., Jiang, T., Jones, M.M., Kuroda, J., Lee, E.Y., Li, Y.-X., MacLeod, K.G., Maritati, A., Martinez, M., O’Connor, L.K., Petrizzo, M.R., Quan, T.M., Richter, C., Riquier, L., Tagliaro, G.T., Tejada, M.L.G., Wainman, C.C., Watkins, D.K., White, L.T., Wolfgring, E., Xu, Z., 2019. Site U1513. In: Hobbs, R.W., Huber, B.T., Bogus, K.A., Expedition 369 Scientists (Eds.), Australia Cretaceous Climate and Tectonics. Proceedings of the International Ocean Discovery Program, 369. IODP, College Station, TX.

Johnston, S., Hackney, R., Nicholson, C., 2010. Distribution of igneous facies and potentialfield modelling of the Mentelle Basin, southwestern margin, Australia. ASEG Extended abstract.

Kaminski, M.A., Gradstein, F.M., 2005. Atlas of Paleogene cosmopolitan deep-water agglutinated foraminifera. Grzybowski Foundation Special Publication 10, 547 pp. http://www.foraminifera.eu/atlas.html

Knaust, D., 2017. Atlas of Trace Fossils in Well Core: appearance, taxonomy and interpretation. Springer International Publishing, 209 pp.

Lech, M.E., Jorgensen, D.C., Southby, C., Wang, L., Nguyen, V., Borissova, I., Lescinksy, D., 2016. Palaeogeographic mapping to understand the hydrocarbon and $\mathrm{CO}_{2}$ storage 
potential of the post-rift Warnbro Group, offshore Vlaming Sub-basin, southern Perth Basin, Australia. Marine and Petroleum Geology 77, 1206-1226.

Lee, E.Y., Novotny, J., Wagreich, M., 2019. Subsidence Analysis. In: Subsidence Analysis and Visualization for sedimentary basin analysis and modelling. SpringerBriefs in Petroleum Geoscience \& Engineering. Springer, Cham, 9-35.

Lee, E.Y., Novotny, J., Wagreich, M., in press. Compaction trend estimation and applications to sedimentary basin reconstruction (BasinVis 2.0). Applied Computing \& Geosciences, 100015.

Mahoney, J.J., Jones, W.B., Frey, F.A., Salters, V.J.M., Pyle, D.G., Davies, H.L., 1995. Geochemical characteristics of lavas from Broken Ridge, the Naturaliste Plateau and southernmost Kerguelen Plateau: Cretaceous plateau volcanism in the southeast Indian Ocean. Chemical Geology 120, 315-345.

Maloney, D., Sargent, C., Direen, N.G., Hobbs, R.W., Gröcke, D.R., 2011. Re-evaluation of the Mentelle Basin, a polyphase rifted margin basin, offshore southwest Australia: new insights from integrated regional seismic datasets. Solid Earth 2, 107-123.

Manville, V., Németh, K., Kano, K., 2009. Source to sink: A review of three decades of progress in the understanding of volcaniclastic processes, deposits, and harzards. Sedimentary Geology 220, 136-161.

Markl, R.G., 1978. Further evidence for the Early Cretaceous breakup of Gondwanaland off southwestern Australia. Marine Geology 26, 41-48.

Martín-Puertas, C., Jiménez-Espejo, F., Martínez-Ruiz, F., Nieto-Moreno, V., Rodrigo, M., Mara, M.P., Valero-Garcés, B.L., 2010. Late Holocene climate variability in the 
southwestern Mediterranean region: an integrated marine and terrestrial geochemical approach. Climate of the Past 6, 807-816.

Martinez, M., Deconinck, J.-F., Pellenard, P., Riquier, L., Company, M., Reboulet, S., Moiroud, M., 2015. Astrochronology of the Valanginian - Hauterivian stages (Early Cretaceous): chronological relationships between the Parana-Etendeka large igneous province and the Weissert and the Faraoni events. Global and Planetary Change 131, $158-173$.

McKenzie, D., 1978. Some remarks on the development of sedimentary basins. Earth and Planetary Science Letters 40, 25-32.

Müller, R.D., Gaina, C., Tikku, A., Mihut, D., Cande, S.C., Stock, J.M., 2000. Mesozoic/Cenozoic tectonic events around Australia, In: Richards, M.A., Gordon, R.G., Van Der Hilst, R.D. (Eds.), History and Dynamics of Global Plate Motions, Geophysical Monograph 121. American Geophysical Union, Washington DC, 161-188.

Murray, J.W., 1991. Ecology and Palaeoecology of Benthic Foraminifera. John Wiley and Sons, New York, 408 pp.

Murray, J.W., 2006. Ecology and Applications of Benthic Foraminifera. Cambridge University Press, Cambridge, 426 pp.

Norvick, M.S., 2004. Tectonic and Stratigraphic History of the Perth Basin. Geoscience Australia Record 2004/16, Canberra.

Ogg, J.G., 2012. Geomagnetic polarity timescale. In: Gradstein, F., Ogg, J.G., Schmitz, M., Ogg, G. (Eds.), The Geologic Time Scale. Elsevier, Amsterdam, 85-113. 
Ogg, J.G., Ogg, G.M., Gradstein, F.M., 2016. Cretaceous. In: Ogg, J.G., Ogg, G.M., Gradstein, F.M. (Eds.), A concise geologic time scale. Elsevier, Amsterdam, 167-186.

Olierook, H.K.H., Barham, M., Fitzsimons, I.C.W., Timms, N.E., Jiang, Q., Evans, N.J., McDonald, B.J., 2019a. Tectonic controls on sediment provenance evolution in rift basins: Detrital zircon $\mathrm{U}-\mathrm{Pb}$ and $\mathrm{Hf}$ isotope analysis from the Perth Basin, Western Australia. Gondwana Research 66, 126-142.

Olierook, H.K.H., Jiang, Q., Jourdan, F., Chiaradia, M., 2019b. Greater Kerguelen large igneous province reveals no role for Kerguelen mantle plume in the continental breakup of eastern Gondwana. Earth and Planetary Science Letters 511, 244-255.

Olierook, H.K.H., Jourdan, F., Merle, R.E., 2019c. Age of the Barremian-Aptian boundary and onset of the Cretaceous Normal Superchron. Earth-Science Reviews 197, 102906.

Olierook, H.K.H., Jourdan, F., Merle, R.E., Timms, N.E., Kusznir, N., Muhling, J.R., 2016. Bunbury Basalt: Gondwana breakup products or earliest vestiges of the Kerguelen mantle plume?. Earth and Planetary Science Letters 440, 20-32.

Olierook, H.K.H., Merle, R.E., Jourdan, F., 2017. Toward a Greater Kerguelen large igneous province: Evolving mantle source contributions in and around the Indian Ocean. Lithos $282-283,163-172$.

Olierook, H.K.H., Merle, R.E., Jourdan, F., Sircombe, K., Fraser, G., Timms, N.E., Nelson, G., Dadd, K.A., Kellerson, L., Borissova, I., 2015a. Age and geochemistry of magmatism on the oceanic Wallaby Plateau and implications for the opening of the Indian Ocean. Geology 43, 971-974. 
Olierook, H.K.H., Timms, N.E., Merle, R.E., Jourdan, F., Wilkes, P.G., 2015b. Paleodrainage and fault development in the southern Perth Basin, Western Australia during and after the breakup of Gondwana from 3D modelling of the Bunbury Basalt. Australian Journal of Earth Sciences 62, 289-305.

Olierook, H.K.H., Timms, N.E., Wellmann, J.F., Corbel, S., Wilkes, P.G., 2015c. A 3D structural and stratigraphic model of the Perth Basin: Implications for sub-basin evolution. Australian Journal of Earth Sciences 62, 447-467.

Peron-Pinvidic, G., Manatschal, G., 2010. From microcontinents to extensional allochthons: witnesses of how continents break apart?. Petroleum Geosciences 16, 189-197.

Reolid, M., Martínez-Ruiz, F., 2012. Comparison of benthic foraminifera and geochemical proxies in shelf deposits from the Upper Jurassic of the Prebetic (southern Spain). Journal of Iberian Geology 38, 449-465.

Sayers, J., Symonds, P.A., Direen, N.G., Bernadel, G., 2001. Nature of the continent- ocean transition on the non- volcanic rifted margin in the central Great Australian Bight, Geological Society Special Publication 187, 51-76.

Schnetger, B., Brumsack, H., Schale, H., Hinrichs, J., Dittert, L. 2000. Geochemical characteristics of deep-sea sediments from the Arabian Sea: a high-resolution study. Deep Sea Research Part II: Topical Studies in Oceanography 47, 2735-2768.

Seilacher, A., 1967. Bathymetry of trace Fossils. Marine Geology 5, 413-428.

Sykes, T.J.S., Kidd, R.B., 1994. Volcanogenic sediment distributions in the Indian Ocean through the Cretaceous and Cenozoic, and their paleoenvironmental implications. Marine Geology 116, 267-291. 
Symonds, P.A., Planke, S., Frey,O., Skogseid, J., 1998. Volcanic evolution of the Western Australian continental margin and its implications for basin development. In: Purcell, P.G.R.R. (Eds.), The Sedimentary Basins of Western Australia 2: Proceedings of the PESA Symposium. Petroleum Exploration Society Australia, Perth, 33-54.

Tejada, M.L.G., Lee, E.Y., Chun, S.S., Harry, D.L., Riquier, L., Wainman, C.C., in press. Data report: Petrology and volcanic stratigraphy at Site U1513, IODP Expedition 369. Proceedings of the International Ocean Discovery Program, 369. IODP, College Station, TX.

Tjalsma, R.C., Lohmann, G.P., 1983. Paleocene-Eocene bathyal and abyssal benthic foraminifera from the Atlantic Ocean. Micropaleontology Special Publications, Book 4, $90 \mathrm{pp}$.

Vallier, T.L., Kidd, R.B., 1977. Volcanic sediments in the Indian Ocean. In: Heirtler, J.R., Bolli, H.M., Davies, T.A., Saunders, J.B., Sclater, J.G. (Eds.), Indian Ocean Geology and Biostratigraphy. American Geophysical Union, 87-118.

van Morkhoven, F.P.C.M., Berggren, W.A., Edewards, A.S., 1986. Cenozoic cosmopolitan deep-water benthic Foraminifera. Bulletin des Centres de Recherches ExplorationProduction Elf-Aquitaine, Memoires 11, $421 \mathrm{pp}$.

Veevers, J.J., Powell, C.McA., Roots, S.R., 1991. Review of seafloor spreading around Australia. I. Synthesis of the patterns of spreading. Australian Journal of Earth Sciences 38, 373-389.

Veevers, J.J., Li, Z.X., 1991. Review of seafloor spreading around Australia. II. Marine magnetic anomaly modelling. Australian Journal of Earth Sciences 38, 391-408. 
Wainman, C.C., Borissova, I., Harry, D.L., Hobbs, R.W., Mantle, D.J., Maritati, A., Lee, E.Y., in press. Evidence for non-marine Jurassic to earliest Cretaceous sediments in the pre-breakup section of the Mentelle Basin, southwestern Australia. Australian Journal of Earth Sciences.

Watson, S.J., Whittaker, J.M., Halpin, J.A., Williams, S.E., Milan, L.A., Daczko, N.R., Wyman, D.A., 2016. Tectonic drivers and the influence of the Kerguelen plume on seafloor spreading during formation of the early Indian Ocean. Gondwana Research, 35, $97-114$.

White, R., McKenzie, D., 1989. Magmatism at rift zones: the generation of volcanic continental margins and flood basalts. Journal of Geophysical Research 94, 7685-7729.

Whittaker, J.M., Williams, S.E., Halpin, J.A., Wild, T.J., Stilwell, J.D., Jourdan, F., Daczko, N.R., 2016. Eastern Indian Ocean microcontinent formation driven by plate motion changes. Earth and Planetary Science Letters 454, 203-212.

Whittaker, J.M., Williams, S.E., Müller, D.R., 2013. Revised tectonic evolution of the Eastern Indian Ocean. Geochemistry Geophysics Geosystems 14, 1891-1909.

Williams, S.E., Whittaker, J.M., Granot, R., Müller, D.R., 2013. Early India-Australia spreading history revealed by newly detected Mesozoic magnetic anomalies in the Perth Abyssal Plain. Journal of Geophysical Research-Solid Earth 118, 3275-3284.

Williams, S.E., Whittaker, J.M., Müller, R.D., 2011. Full- fit, palinspastic reconstruction of the conjugate Australian- Antarctic margins. Tectonics 30, TC6012. 
Zhu, D.-C., Chung, S.-L., Mo, X.-X., Zhao, Z.-D., Niu, Y., Song, B., Yang, Y.-H., 2009. The 132 Ma Comei-Bunbury large igneous province: Remnants identified in present-day southeastern Tibet and southwestern Australia. Geology 37, 583-586. 


\section{Figures}

Figure 1. A) Map of Naturaliste Plateau (NP), Mentelle Basin (MB), and southern Perth Basin with respect to mainland Australia (inset) (revised from Borissova, 2002), showing locations of IODP Sites U1513, U1515 (yellow circles), DSDP Sites 258, 264 (white circles), faults (grey lines) and a seismic section (red line, shown in B). The bathymetric contour interval is $500 \mathrm{~m}$ and the Naturaliste Plateau is defined approximately by the 4000 -m contour. B) Seismic line S310/07 (provided by Geoscience Australia) showing Site U1513 location, general lithostratigraphy, the extent of the volcaniclastic-rich sequence (yellow shade), projected location of Site U1515, and structural characteristics. Dashed green line indicates bottom of the Albian strata.

Figure 2. Plate reconstruction of the Naturaliste Plateau $(\mathrm{N})$ and surrounding regions with IODP Site U1513 location (green star) at $130 \mathrm{Ma}, 120 \mathrm{Ma}, 100 \mathrm{Ma}$ (revised from Gibbons et al., 2012). Volcanic rock occurrences (red areas) and volcaniclastic deposit sites (orange dots) are inferred from previous studies (Borissova et al., 2003; Direen et al., 2017; Ghose et al., 2017; Hayes et al., 1975; Hu et al., 2010; Olierook et al., 2015a, 2015b; Whittaker et al., 2016; Zhu et al., 2009). AAP: Argo Abyssal Plain, BB: Bunbury Basalt, BK: Batavia Knoll, BR: Bruce Rise, CAP: Cuvier Abyssal Plain, CB: Comei Basalt, E: Exmouth Plateau, EB: Elan Bank, GAP: Gascoyne Abyssal Plain, GK: Gulden Draak Knoll, K: Kerguelen Plateau, M: Mentelle Basin, P: Perth Basin, PAP: Perth Abyssal Plain, RSB: Rajmahal-Sylhet Basalt, W: Wallaby Plateau, Z: Zenith Plateau. 
Figure 3. A) Lithostratigraphic profiles of IODP Site U1513 and DSDP Sites 258, 264 drilled on the Naturaliste Plateau (Davies et al., 1974; Hayes et al., 1975; Huber et al., 2019), together with ages and magnetic susceptibility (ms) of Site U1513. B) Al-Zr-Ti ternary plot for sediments, sedimentary and volcanic rocks recovered from Site U1513. Values for Al (multiplied by 10 ), $\mathrm{Ti}$ (multiplied by 100 ) in $\mathrm{wt} \%$ and $\mathrm{Zr}$ in ppm are normalized to $100 \%$. Factors for $\mathrm{Al}$ and $\mathrm{Ti}$ were used to position the dots closer to the middle of the diagram. Yellow dots are data from the volcaniclastic-rich sequence of Unit V. For Unit VI, red circle represents mean data from basalt and dolerite dike samples, and red dots are data from volcaniclastic beds. Open circles present the mean data from volcanic rocks; dredged samples (Direen et al., 2017) and volcanic fragments at Site 264 (Ford, 1975) of the southern Naturaliste Plateau (SNP; pink), dredged samples (Coleman et al., 1982; Mahoney et al., 1995) of the northern Naturaliste Plateau (NNP; orange), and outcrop samples (Olierook et al., 2016) of the Bunbury Basalt (BB; brown).

Figure 4. A) Lithologic profile of the volcaniclastic-rich sequence (Unit V) with Hole U1513D core numbers and Subunits 1-4. B) Core-section images. Subunit 1: massive sandstone with volcanic clasts and calcite cementation (462.02-462.32 mbsf; interval U1513D-42R-2, 80-110 cm) and low angle to planar stratified sandstone with pyrites (464.58-464.88 mbsf; interval U1513D-42R-4, 100-130 cm), Subunit 2: silty claystone with interbedded sandstone layers and soft-sediment deformation (494.36-494.66 mbsf; interval U1513D-45R-5, 60-90 cm), Subunit 3: massive sandy siltstone with slight bioturbation and pyrites (540.27-540.57 mbsf; interval U1513D-50R-3, 65-95 cm), Subunit 4: massive glauconitic sandstone with volcanic clasts and lithic fragments (636.37-636.67 mbsf; interval U1513D-60R-4, 63-93 cm) and low angle to planar stratified clayey sandstone with volcanic 
clasts, bioturbation and pyrites (598.07-598.37 mbsf; interval U1513D-56R-3, 103-133 cm).

C) Macroscopic and microscopic observations of distribution of volcanic clasts, lithic fragments, bioturbation, shell fragments, plant debris and unidentified organic matter. Images of pollens, volcanic clasts (thin-section image; Sample U1513D-42R-2, 138-143 cm), shell fragments, plant debris and trace fossils. S: Spiniferites sp., Ce: Cribroperidinium edwardsii, Ag: Apteodinium granulatum, Ch/v: Circulodinium hystrix/vannophorum, A: Apteodinium sp., L/I: Leptodinium/Impagidinium sp.

Figure 5. A) Magnetostratigraphic age-depth model for the volcaniclastic-rich sequence (Unit V) of Hole U1513D (Huber et al., 2019 with ages from Ogg et al., 2012, 2016). Eighteen magnetic polarity reversals from chrons M10Nn.1n to M0r between 690.25 and 455.47 mbsf. Lithologic profile and subunit ranges of Unit V are from Fig. 4A. B) Sedimentation rate vs. age plot with a lithologic profile based on magnetostratigraphic units. Dashed pink lines are evaluated from present (compacted) layer thickness, and solid lines from restored (decompacted) layer thickness. C) $\mathrm{Mg} / \mathrm{Al}$ (in purple) and $\mathrm{Rb} / \mathrm{Al}$ (in orange) ratios vs. age.

Figure 6. A) Early Cretaceous global sea-level (SL) curves (Haq, 2014). B) Early Cretaceous subsidence history of the Naturaliste Plateau at Site U1513 with Units VI to IV and subunits of Unit V. Subsidence curve represents the top depth of volcanic sequence, which is the accumulated thickness of volcaniclastic-rich strata in addition to estimated paleobathymetry. Major tectonic events are shown with volcanic eruption periods of the Naturaliste Plateau 
(NP; Direen et al., 2017), Bunbury Basalt (BB; Olierook et al., 2016), Kerguelen Plateau (KP; Coffin et al., 2002) and Gulden Draak Knoll (GK; Whittaker et al., 2016). 


\section{Declaration of interests}

$\bigotimes$ The authors declare that they have no known competing financial interests or personal relationships that could have appeared to influence the work reported in this paper.

$\square$ The authors declare the following financial interests/personal relationships which may be considered as potential competing interests: 

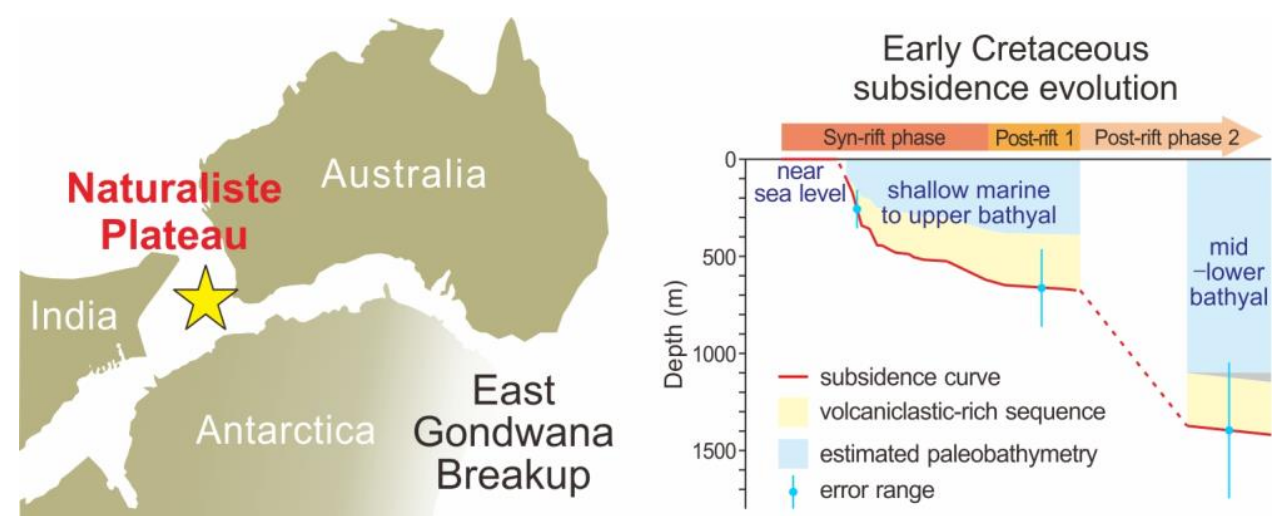

Graphical abstract 


\section{Highlights}

Lower Cretaceous strata at IODP Site U1513 on the Naturaliste Plateau span breakup.

Volcaniclastic-rich strata have a deepening record from shelf to upper bathyal depths.

A late syn-rift phase to two-phase post-rift subsidence history is revealed. 